\title{
Reunderstanding and Reconstructing the Form of Folk Belief Statements in Minangkabau Society
}

\author{
Noni Febriana, Robby Dharma \\ Universitas Putra Indonesia, Padang \\ noniefebrian@yahoo.com
}

\begin{abstract}
This article aimed to describe reunderstanding and reconstructing the form of folk belief statements in Minangkabau society. This research was a content analysis researh using descriptive qualitative method. The research was done in 4 places in city of Padang namely: Padang Barat, Padang Timur, Padang Utara, and Padang Selatan. The data in this research were the statements of folk belief statements in Minangkabau society which is obtained from observation and indepth interview with penghulu, cerdik pandai, and alim ulama. Based on the discussion, there were two things that can be concluded. First, the form of folk belief statements in Minangkabau society can be reconstructed from the agent: pregnant woman, girls, and boys. Second, the form of folk belief statements in Minangkabau society can be reconstructed from the action: work, sign, and health. These forms are focus on the context and the folk belief statements such as: sit, sweep, play, work, walk, eat, and other daily activities which are not appropriate.
\end{abstract}

Keywords---reunderstanding, reconstruction, folk belief statements form, Minangkabau society

\section{INTRODUCTION}

Folk belief is one kind of oral folklore. It can be understood as the effort of a speaker to a group of people in delivering the information using appropriate feeling, view and emotion in order to make the people know and understand about the implicit meaning in the statement (Danandjaya, 1991).

In line with Danandjaya (1991), Ingemark (2007, p. 281) states that "Taking the oral traditions constituting ancient folklore as a point of departure, it is also possible to aproach the social reality and mentality of the period from a slightly different angle". Moreover, Danandjaja explains that in Indonesia, folklore is defined as: those meterials in culture that circulate traditionally among members of any group in different versions, whether in oral form, or by means of customary example. Thus folk in Indonesia means: any group, native or immigrant, as long as they have lived in Indonesia for generations, urban as well as rural, literate or illiterate, noble or commoner, and lore: is the part of Indonesian cultures that is disseminated though oral tradition (Danandjaya, 1995, p. 205).

There are several researches which explore the character of Minangkabau's people based on local wisdom in form of oral literature. First, the research done by Ermanto (2009) entitled "Fenomena Masyarakat Minangkabau dalam Cerpen Si Padang karya Harris Effendi Thahar dan Robohnya Surau Kami karya A.A. Navis: Pemahaman Sastra dengan Pendekatan Kebahasaan." (Phenomena of Minangkabau's people in Si Padang short story written by Harris Effendi Thahar and Robohnya Surau Kami short story written by A.A. Navis: Literature Understanding using Linguistic Approach). Based on the research, it can be concluded that: (1) the title of the short stories describe the phenomena of life in Minangkabau; (2) the name of the characters in the stories describe the relationship of Minangkabau and Islam; (3) the culture of going abroad for Minangkabau's people; (4) the culture of story telling and talking of Minangkabau's people; (5) the courage of Minangkabau's people in giving voice about something that they believed as the rightness; (6) the change of Minangkabau's family relationship, from extended family into nuclear family and; (7) the change of people's behavior in abroad.

Second is the research done by Sartika (2009) about "Nilai-Nilai Pendidikan dalam Ungkapan Kepercayaan Masyarakat suku Bungus di Desa Tanah Merah Kecamatan Tanah Merah Kabupaten Indogiri Hilir Riau", (Educational values in Folk Belief of people in Bungus Ethnic Group in Desa Tanah Merah Kecamatan Tanah Merah Kabupaten Indogiri Hilir Riau). In this research, it was found that there are social, physical, religion and family welfare educational values in society's folk belief. Third is the research done by Ulya (2018) entitled "Cultural Manifestation in Superstition of Minangkabau Society." In detail, Ulya (2018) investigated aspect of ethical values in folk belief (he used the term of superstition). The ethical values are connected with the behavior known as sumbang duo baleh. 
Ulya (2018) states that folk belief or superstition is the form of social order for Minangkabau's people. Folk belief is believed as positive content with values that can be used as the reflection of the society in behaving. Moreover, folk belief is one of the strategies used by parents in controlling misbehavior done by the children at home or in the society.

Superstition is the statement contains supernatural or unusual information. Superstition is a part of folklore (or culture) and it contains of ethic or how we behave in social life. In other words, there is a well-mannered content in superstition since it is the part of culture. The characteristic of Minangkabau's society is local wisdom arranged in well-mannered norms. The norm is called as sumbang duo baleh.

Based on the previous researches, it is important to explore the actualization of educational values in Minangkabau folk belief. The actualization usage of folk belief in Minangkabau society aims to guide the people in formal and non formal situation and aplication. The examples of formal situation are in marriage ceremony, funeral ceremony, baby blessing ceremony, circumcision ceremony, etc. The example of non formal situation is daily conversation. The educational values in folk belief is still actualized and used by the society in educating the nephews/nieces by the mother's brother, the children by the father, and the children by the mother and also the youth by the older people.

This present research is focus on knowing and describing the reunderstanding and reconstruction form of folk belief statements in Minangkabau. It is hoped that this research can enrich the readers' insight about the process of educational values in Minangkabau's folk belief as the effort in guiding the society or parents in educate the children at home.

\section{METHODS}

This paper was a content analysis research using descriptive qualitative method. The research was done in 4 subdistricts in Padang City: Padang Barat, Padang Timur, Padang Utara and Padang Selatan. Besides, the data was conducted by using interview with 12 informants ( 3 informants in each subdistrict). The data in this research were folk belief statements in Minangkabau society especially in Padang City that was gotten from observation and interview the informants (penghulu, cerdik pandai, and alim ulama). The validity of the reserach was done through distributional technique. It means that valid data was selected, identified, and distributed based on the classification and category of the theory. The data analysis in this research used content analysis method, heuristic dan hermeneutic method. The steps of data analysis in this research were: (1) inventorying the data from several informants using observation technique, interview and recording, (2) transcripting the recorded data into written form, (3) translating the data into Indonesian language, (4) grouping the folk belief statements based on the form and local wisdom reflection, (5) concluding the findings of the research.

\section{FINDING AND DISCUSSION}

Based on the research, it can be understood that the way of delivering information by Minangkabau's people is known as folk belief. Folk belief statements in Minangkabau aim to give such advices to someone who does not obey the rules and cultures in Minangkabau. These statements are spoken by older people to younger people in order to avoid them from danger. So that, important to research about folk belief statements reunderstanding and reconstructing need to be done in order to avoid miscommunication in form of statement from the side of agent and behavior. The explanation the forms of folk belief statements in Minangkabau society can be seen as follow:

\section{The form of folk belief statements from the agent}

Result of research done by Ulya (2016) shows that superstition is told when a child or society act bad or out of the norm in tradition. If a child do bad thing (if sumbang happen), parent will use superstition as the tool to give deterrent effect to the child. Besides, local wisdom value in superstition contain of how a person should behave in some matters such as sit, stand, walk, work, etc. It is similar with this present research in which the folk belief statement should be stated by order people such as: mother, father, mamak, etc. Based on the data analysis it can be understood that there are three of folk belief statement from the agent. Folk belief statement from the agent can be seen as follow:

\section{a. Folk belief statements for pregnant women}

One of the forms of folk belief in Minangkabau is to give some advices to pregnant women. Pregnant women have a lot of avoidance and they have to sit, stand, eat, sleep and do other activities in righ ways. These are to make the baby born safely and in good condition. It is relevant with the women status in Minangkabau in the highest position. The generation born should be good and hopefully can keep the good reputation of the family. Folk belief statements for pregnant woman can be seen as follow: 
Datum (12) Urang hamil indak buliah mancacek urang, beko model itu pulo parangai anaknyo. (It is not allowed for pregnant woman to insult other people, if not the baby will be like the person that she insulted)

This statement relates with educational function in form of words. In textual meaning, this statement means that it is not allowed for pregnant woman to insult other people, if not the baby will be like the person that she insulted. In latent meaning, this statement aims to make pregnant woman to have good behavior for the baby later.

Datum (13) Urang hamil indak buliah malilik salendang, beko taliliak pulo pusek anak. (Pregnant woman is not allowed to twist the scarf if not the baby's navel will be twisted)

This statement relates with educational function in form of work. In textual meaning, this statement means that pregnant woman is not allowed to twist the scarf if not the baby's navel will be twisted. In latent meaning, this statement is made in order to make the pregnant woman not to twist the scarf around the neck that can disturb her respiration

\section{b. Folk belief statements for girls}

Girls in Minangkabau should be taken care and have good behavior. They must follow a lot of rules related to behavior, so that there are also a lot of folk belief statement related with them . Folk belief statements for girls can be seen as follow:

Datum (1) Indak buliah anak gadiah nyapu rumah katiko magrib, beko tasapu anak dubilih. (It is not allowed for a girl to sweep the floor during the dusk, if not she will sweep the devil)

This statement relates with the function of education in form of work. In textual meaning, a girl is not allowed to sweep the floor during the dusk; the reason is to prohibit the girls in doing the house chores in the time of Moslem people do Maghrib Pray in dusk. It means that, the statement is used in order to make the girl do the Maghrib Pray soon since the time of pray is short. The statement is used by the parents since the girls afraid of evil spirit/ ghost things and immediately does the Maghrib Pray.

Datum (2) Anak gadih ndak buliah bajalan waktu magrib masuk, buruak cando tampak dek urang nan banyak. (A girl is not allowed to walk during the Maghrib Pray; it is not good to be seen by other people)

The statement is related with the function of education about travel. In textual meaning, a girl is not allowed to walk outside the house during the dusk (Maghrib Pray) because it is not good to be seen by others. During the dusk, it is going to be dark, and darkness is symbolized as misfortune and disaster, so that the parents prohibit the children to go outside during the dusk.

Data (15) Anak gadih indak elok mengudok samba, beko buruak dicaliak urang. (Girls are not allowed to eat side dish without main dish; it is not good to be seen by other people)

This statement relates with educational values in form of work. In textual meaning, this statement means that girls are not allowed to eat side dish without main dish (rice); it is not good to be seen by other people. In latent meaning, it aims to make the other family member get the equal number of side dish while eating and prohibit the girl/ children to eat the side dish without the main dish (rice) and make the other family member do not get the side dish during the lunch or dinner.

Datum (21) Anak gadih indak buliah duduk di pintu sanjo, beko indak dapek laki. (Girl is not allowed to sit in front of the door at dusk or she will not get a husband)

This statement relates with educational values in form of work. In textual meaning, this statement means that girl is not allowed to sit in front of the door at dusk or she will not get a husband in the future. In latent meaning, this statement means that children must not sit in front of the door because it will block the way people who want to go outside or indise the house. Moreover, during the dusk, the children must do Maghrib Pray and not sitting in front of the door. The use of phrase beko indak dapek laki (not get a husband in the future) will make the girls afraid of not getting a husband in the future and avoid sitting in front of the door.

\section{c. Folk belief statements for boys}

Boys in Minangkabau take role as the leader. They are educated to be responsible in doing everything and in talking. Folk belief statement for boys can be seen as follow:

Datum (14) Laki-laki indak buliah bajalan jauh pado hari jum'at, beko indak salamaik awak di jalan. (Man is not allowed to take a long trip on Friday or he will not be safe on the road) 
This statement relates with educational values in form of traveling. In textual meaning, this statement means that man is not allowed to take a long trip on Friday or he will not be safe on the road. In latent meaning, this statement is made in order to make men not to take a long trip on Friday because he will miss the Friday pray (for Moslem man in Islam). The statement use the phrase beko indak salamaik awak di jalan in order to make the children afraid of taking a long trip on Friday and do Jumat pray.

\section{Folk belief statement based on the action and behavior done}

The result of this research shows that the form of folk belief statement of Minangkabau society can be reconstructed based on the action and behavior done. It means that folk belief is not also can be seen from the agent point of view but also from the action done. Based on the action done, the statements are written for all people in all age and general. Besides, form of folk belief seen from action or behavior done can be seen from the context of the violation.

It is similar with the research done by Ulya (2017) who states that "Konteks merupakan salah satu aspek penting dalam superstisi atau ungkapan larangan." Context is one important aspect in superstition or folk belief". The context here related with ethic, proper behavior or also known as sumbang duo baleh (twelve proper behaviors), such as sitting, standing, socializing, dressing, asking questions, answering questions, having good behavior, silent, walking and working (Ulya,2017). The conclusion of Ulya's research was related with this present research. Result of data analysis shows that the form of folk belief statements in Minangkabau society is based on the behavior violation which is related with the context. The following is the explanation of folk belief statement based on the action done.

\section{a. Form of folk belief statements in form of work}

Form of folk belief statements in form of work aims to warn the agent to change bad behavior. The behavior is such as: sweeping, throwing something, pointing something, eating, sleeping, etc. These forms can be seen as follow:

Datum (3) Jan mambae di hari sanjo, beko kanai anak dubilih. (It is not allowed to throw something during the dusk, it will hit the devil)

The statement is related with the function of education about work. In textual meaning, it means that it is not good to throw something during the dusk because it will accidentally hit someone since the condition is dark during the dusk. The parent use the statement related with devil to make the children afraid to do it.

Datum (6) Jan pai kakuburan sanjo, beko tasapo. (It is not allowed to go the graveyard at dusk unless you will be possessed by evil spirit)

This statement relates with aducational function in form of health. The statement in textual meaning is the prohibition to not visiting graveyard at dusk because the evil spirit will possess us. In latent meaning, it can be understood that at dusk, the sky is going to be dark, and it is not the right time to visit the graveyard or doing other activities. Besides, at dusk, the children must prepare for doing Maghrib pray (for Moslem people), the statement is made in order to make the children afraid of doing other activities beside Maghrib Pray at dusk.

Datum (7) Jan duduak di ateh banta, beko bisua pulo ikua. (It is not allowed to sit on the pillow or we will get abscess at the bottom)

This statement relates with educational function in form of work. The statement in textual means that we are not allowed sitting on the pillow or we will get abscess at the bottom. In latent meaning, it means that the pillow is used for the head when sleep and it is not appropriate to be used at the bottom

Datum (8) Jan makan banyak rimah, beko managih nasi. (It is not allowed to eat in mussy, if not the rice will cry) This statement relates with educational function in form of work. In textual meaning, this statement prohibits the children to eat in a mess because it will make the rice sad and cry. In latent meaning, it aims to make the children not to waste the food. The parent use the phrase

beko managih nasi (the rice will cry) in order to make the children eat in tidy and not wasting the food

Datum (9) Indak buliah lalok sanjo, bekonyo impik dek setan. (It is not allowed to sleep at dusk or the devil will squeeze on us)

This statement relates with the educational function in form of work. In textual meaning, this statement prohibit us to sleep at dusk, since the dusk is the time for moslem people to do maghrib pray and it has short time. The parent use the phrase related with devil in order to make the children afraid and will do the pray immediately. 
Data (10) Indak buliah basiul malam hari, beko datang ula. (It is not allowed to whistle at night or the snake will come) This statement relates with educational function in form of work. In textual meaning, it is not allowed to whistle at night or the snake will come. In latent meaning, it aims to make the children not to whistle since it is noisy and annoy the member of the family who wants to take a rest at night.

Datum (11) Jikok minum di galeh sumbiang, beko sumbiang pulo anak. (It is not allowed to drink using chipped glass or we will get harelip)

This statement relates with educational function in form of work. In textual meaning it is not allowed to drink using chipped glass or we will get harelip. In latent meaning, this statement prohibit the children not to drink using chipped glass in order to avoid the lip get injured.

Datum (16) Jikok manempati rumah baru, jan lupo kito mandarahan saikua ayam. (If we have new house, do not forget to bedgraggled the chicken blood to the house)

This statement relates with educational values in form of work. In textual meaning, this statement means that if we have new house, do not forget to bedgraggled the chicken blood to the house. In latent meaning, this statement means that after building the new house, the owner should make such a celebration by inviting the neighbor as the way to express the gratitude.

Datum (18) Indak buliah bapayuang dalam rumah, beko ditembak patuih. (It is not allowed to use umbrella inside the house, or we will get struck by thunder)

This statement relates with educational values in form of work. In textual meaning, this statement means that it is not allowed to use umbrella inside the house, or we will get struck by thunder. In latent meaning, this statement makes the children not to play with the umbrella inside the house since it can disturb the other members of the family

Datum (19) Indak buliah manunjuak palangi, beko bengkok jari tangan. (It is not allowed to point at the rainbow or the point finger will bend)

This statement relates with educational values in form of work. In textual meaning, this statement means that it is not allowed to point at the rainbow or the point finger will bent. In latent meaning, this statement means that point at the rainbow will make the other people become annoyed and uncomfortable. So the parents use the phrase beko bengkok jari tangan to make the children afraid if their fingers bent.

Datum (22) Indak buliah mancigok urang mandi, beko bisua mato. (It is not allowed to peek on someone who take a bath in the bathroom or we will get abscess on the eyes)

This statement relates with educational values in form of work. In textual meaning, this statement means that it is not allowed to peek on someone who takes a bath in the bathroom or we will get abscess on the eyes. In latent meaning, this statement means that peeking someone while taking a bath is not appropriate and prohibit by the religion. So parents use this statement to make the children afraid of having abscess on the eyes if they peek on someone when taking a bath.

Datum (23) Indak buliah malompek-lompek sanjo hari, beko laweh tapak kaki. (It is not allowed to jump at dusk or the sole of the feet will grow wide)

This statement relates with educational values in form of work. In textual meaning, this statement means that it is not allowed to jump at dusk or the sole of the feet will grow wide. In latent meaning, this statement means to prohibit the children not to jump at dusk in order to avoid them fall down and injure themselves. So parents use this statement to make the children afraid of having wide sole of feet.

\section{b. Form of folk belief statements in form of sign}

This form aims to give association relationship and tend to predict the future. These form can be seen as follow:

Datum (4) Kalau ado kupu ramo-ramo datang karumah, tando ado urang kamati di keluarga awak. (If there is a butterfly inside the house, it means one of the family members will die soon)

The statement is related with the function of education about sign. In textual meaning, it means that, Minangkabau people belief that butterflies are beautiful creature, and the statement aims to make the children do not kill or disturb the butterfly when it is inside the house. 


\section{c. Form of folk belief statements in form of health} follow:

This form of folk belief statements related with the function of human body. The explanation can be seen as

Datum (5) Indak buliah mandi malam, beko di piciak dek setan. (It is not allowed to take a bath at night, because the devil will pinch us)

This statement is related with educational function about health. The statement prohibit the children not to take a bath at night for health reason. At night, the water in the bathroom becomes colder and if we take a bath with the cold water, our heart will beat faster and it is not good for the respiration. So that parents use the phrase of beko di piciak dek setan since the children mostly afraid of devil.

Datum (17) Kok lalok jan manungkuik, beko mati pulo mande. (It is not allowed for someone to sleep face downward or his/her mother will die)

This statement relates with educational values in form of work. In textual meaning, this statement means that it is not allowed for someone to sleep face downward or his/her mother will die. In latent meaning, this statement means that sleeping face downward will make the chest pain. Parents use the phrase beko mati pulo mande (mother will die) in order to make the children afraid of losing mother if they do that.

Datum (20) Jan mangecek jikok makan, beko tacakiak. (It is not allowed to talk during eating or we will get choked)

This statement relates with educational values in form of work. In textual meaning, this statement means that it is not allowed to talk during eating or we will get choked. In latent meaning, this statement means that it is not appropriate for someone to talk while eating because it has negative effect to the body and health

Datum (24) Indak buliah ma agah anak ketek di ateh kapalo, beko sela matonyo. (It is not allowed to see and play with the baby from upside of his/her head or the baby will get crossed-eyes)

This statement relates with educational values in form of work. In textual meaning, this statement means that it is not allowed to see and play with the baby from upside of his/her head or the baby will get crossed-eyes. In latent meaning, this statement means that by playing with the baby and see him/her from the upside of the head will make the baby's neck hurt and pain

Datum (25) Indak buliah manyumpahan anak, beko bano utak anak. (It is not allowed to curse the children, it will make them stupid)

This statement relates with educational values in form of work. In textual meaning, this statement means that it is not allowed to curse the children, it will make them stupid. In latent meaning, this statement means that parents must not curse their children because it will be imitated by the children. Parents should be a role model for the children to have good behavior

Datum (26) Indak buliah manjahik baju malam hari, beko rabun mato awak. (It is not allowed to sew the clothes at night or our eyes will blind)

This statement relates with educational values in form of work. In textual meaning, this statement means that it is not allowed to sew the clothes at night or our eyes will blind. In latent meaning, this statement aims to make the children not sew the clothes at night to avoid them injure themselves. So the parents use the phrase beko rabun mato awak (our eyes will be blind) to make the children afraid of being blind and avoid sewing the clothes at night.

\section{CONCLUSION AND DISCUSSION}

Based on the discussion, there are two things that can be concluded. First, the form of folk belief statements in Minangkabau society can be reconstructed from the agent: pregnant woman, girls, and boys. Besides, girls are dominantly receiving more folk belief statements than boys since girls have some restriction in behaving. Second, the form of folk belief statements in Minangkabau society can be reconstructed from the action: work, sign, and health. These form are focus on the context and the folk belief statements such as: sit, sweep, play, work, walk, eat, and other daily activities which are not appropriate. 


\section{References}

Danandjaja, J. (1991). Folklor indonesia: Ilmu gosip, dongeng, dan lain-lain. Jakarta: Pustaka Utama Grafiti.

$$
213 .
$$

(1995). A Comparative Study of Japanese and Indonesia Folklores. Southeast Asian Studies. 33 (3). p.202-

Ermanto. (2009). Fenomena Masyarakat Minangkabau dalam Cerpen Si Padang karya Harris Effendi Thahar dan Robohnya Surau Kami karya A.A. Navis: Pemahaman Sastra dengan Pendekatan Kebahasaan" dalam Jurnal Pendidikan dan Kebudayaan 15 (5) Tahun 2009. Padang: FBSS UNP.

Ingemark, D., \& C. Asplund. (2007). Teaching Ancient Folklore. The Classical Journal. 102 (3), p. 279-289.

Sartika, Dwi. (2009). Nilai-Nilai Pendidikan dalam Ungkapan Kepercayaan Masyarakat Suku Bungus di Desa Tanah Merah Kecamatan Tanah Merah Kabupaten Indogiri Hilir Riau. Skripsi. Padang: Jurusan Bahasa dan Sastra Indonesia FBSS UNP.

Ulya, R. H. (2016). Aksiologis Sastra dalam Gamitan Nilai Etika pada Superstisi Masyarakat Kubuang Tigo Baleh. ASEAN Comparative Education Research Network Conference (ACER-N) Proceeding, p. 1223-1233.

Ulya, R. H. (2017). Mustika Adab Masyarakat Kubuang Tigo Baleh dalam Bingkai Superstisi dan Sumbang Duo Baleh. International Seminar on Education, Language, Literature, and Art (ISELLA) Proceeding, Universitas Islam Riau, p. 476-490.

Ulya, R. H. (2018). Cultural Manifestation in Superstition of Minangkabau Society. International Conference Education Social Sciences Technology (ICESST) Proceeding, Universitas Negeri Padang, p. 422-429. 